\title{
Determination of the Cellular lon Concentration in Saccharomyces cerevisiae Using ICP-AES
}

\author{
Louise Thines ${ }^{1}$, Anne Iserentant ${ }^{2}$ and Pierre Morsomme ${ }^{1, *}$
}

${ }^{1}$ Louvain Institute of Biomolecular Science and Technology, UCLouvain, Belgium; ${ }^{2}$ Earth and Life Institute, UCLouvain, Belgium

*For correspondence: pierre.morsomme@uclouvain.be

[Abstract] The yeast Saccharomyces cerevisiae has been perceived over decades as a highly valuable model organism for the investigation of ion homeostasis. Indeed, many of the genes and biological systems that function in yeast ion homeostasis are conserved throughout unicellular eukaryotes to humans. In this context, measurement of the yeast cellular ionic content provides information regarding yeast response to gene deletion or exposure to chemicals for instance. We propose here a protocol that we tested for the analysis of 12 elements $\left(\mathrm{Ba}^{2+}, \mathrm{Ca}^{2+}, \mathrm{Cd}^{2+}, \mathrm{Co}^{2+}, \mathrm{Cu}^{2+}\right.$, $\mathrm{Fe}^{2+}, \mathrm{K}^{+}, \mathrm{Mg}^{2+}, \mathrm{Mn}^{2+}, \mathrm{Na}^{+}, \mathrm{Ni}^{2+}, \mathrm{Zn}^{2+}$ ) in yeast using Inductively Coupled Plasma-Atomic Emission Spectrometry (ICP-AES). This technique enables determination of the cellular content of numerous ions from one biological sample.

Keywords: Ion content, Metal, ICP-AES, Yeast, S. cerevisiae

[Background] Yeast has been extensively used to study the ionic response after gene deletion, modification of the extracellular environment, or heterologous protein production for example. In this context, having methods to monitor the ionic status of yeast cells is of high interest. ICP-AES uses high-energy plasma from an inert gas like argon to burn analytes very rapidly. The color that is emitted from the analyte is indicative of the elements present, and the intensity of the spectral signal is indicative of the concentration of these elements. Compared with other techniques (for example spectrophotometric methods, atomic absorption spectrometry and atomic fluorescence spectrometry), ICP-AES is a multi-ion analysis method involving simple and fast procedure with relatively low detection limits (Dahlquist and Knoll, 1978). The method described here applies to concentration determination of $\mathrm{Ba}^{2+}, \mathrm{Ca}^{2+}, \mathrm{Cd}^{2+}, \mathrm{Co}^{2+}, \mathrm{Cu}^{2+}, \mathrm{Fe}^{2+}, \mathrm{K}^{+}, \mathrm{Mg}^{2+}, \mathrm{Mn}^{2+}, \mathrm{Na}^{+}, \mathrm{Ni}^{2+}$, and $\mathrm{Zn}^{2+}$, with the possibility of measurement of numerous cellular ionic concentrations from one $100 \mathrm{ml}$ yeast culture (Eide et al., 2005; Thines et al., 2018). While this protocol has been tested in our laboratory for these twelve ions, this protocol could most likely be transferred to other elements. Besides, although described here for whole-cell measurement of the yeast ionic content, this method could be transferred to other cell types or to isolated organelles by fractionation on sucrose gradient for instance.

\section{Materials and Reagents}

1. Petri dishes (Sigma-Aldrich, catalog number: P5606-400EA)

2. Toothpicks 
3. $5 \mathrm{ml}$ pipette (Gilson, catalog number: F123607)

4. $25 \mathrm{~mm}$ diameter Whatman $^{\circledR}$ glass microfiber filters, grade GF/F (GE Healthcare, catalog number: 1825-025)

5. Saccharomyces cerevisiae strains to be analyzed (performed here on BY4741 or BY4742 S. cerevisiae strains)

6. Yeast extract KAT (Ohly, catalog number: OHLY ${ }^{\circledR}$ KAT)

7. Glucose (Merck, catalog number: 1083469029)

8. EGTA (Acros Organic, catalog number: 409910250)

9. $\mathrm{HCl} 37 \%$ (VWR, catalog number: 20255.29)

10. Suprapur ${ }^{\circledR}$ nitric acid $65 \%$ (Merck, catalog number: 100441)

11. Certipur ${ }^{\circledR}$ single-element standards for inductively coupled plasma spectroscopy (Merck, catalog number: depends on the ion to be analyzed)

12. Milli $Q$ water

13. $\mathrm{NaOH}$ (Sigma-Aldrich, catalog number: S5881)

14. YD plates (see Recipes)

15. YD medium (see Recipes)

16. 1 mM EGTA (1 L) (see Recipes)

\section{Equipment}

1. $500 \mathrm{ml}$ Erlenmeyer (VWR, catalog number: 734-1833)

2. $250 \mathrm{ml}$ glass beakers (VWR, catalog number: 213-1124P)

3. $100 \mathrm{ml}$ graduated cylinders (VWR, catalog number: 612-3836)

4. Haldenwanger ${ }^{\mathrm{TM}}$ porcelain crucibles (Thermo Fisher Scientific, catalog number: 12306507)

5. Analytical balance (Mettler Toledo, catalog number: AB104-S)

6. Filter holding manifold (Hoefer, catalog number: FH225V)

7. Laboratory oven (Utest, catalog number: UTD)

8. Desiccator (VWR, catalog number: 467-0071P)

9. Carbolite ${ }^{\circledR}$ muffle furnace (Sigma-Aldrich, catalog number: Z654973)

10. iCAP 6500 ICP-OES CID spectrometer (Thermo Fisher Scientific, discontinued)

\section{Procedure}

A. Sample preparation

1. Streak the S. cerevisiae strains to be analyzed on YD plates (Recipe 1). Incubate for two days at $28^{\circ} \mathrm{C}$.

2. Using a sterile toothpick, select individual colonies.

3. Re-suspend cells in $100 \mathrm{ml}$ YD medium (in $500 \mathrm{ml}$ Erlenmeyer) (Recipe 2) and grow them at $28^{\circ} \mathrm{C}$ under agitation $(120 \mathrm{rpm})$ to an $\mathrm{OD}_{600}$ of $3\left(\mathrm{OD}_{600}=1\right.$ corresponds to a density of $1.25 \mathrm{x}$ 
$\left.10^{7} \mathrm{cells} / \mathrm{ml}\right)$.

Note: Wash the $500 \mathrm{ml}$ Erlenmeyer with $10 \% \mathrm{HCl}$ before yeast growth to avoid any impact of the detergents used for washing the glassware on the ionic content measurement. Rinse them with Milli $Q$ water and allow them to dry.

4. Filter the $100 \mathrm{ml}$ culture using glass microfiber filters on the filter holding manifold at $4{ }^{\circ} \mathrm{C}$.

5. Wash cells twice on the filter with $2 \mathrm{ml} \mathrm{EGTA} 1 \mathrm{mM}$ (Recipe 3 ) at $4{ }^{\circ} \mathrm{C}$.

6. Wash cells twice with $2 \mathrm{ml}$ Milli $\mathrm{Q}$ water at $4{ }^{\circ} \mathrm{C}$.

7. Immerge each filter in a heat-resistant porcelain crucible containing $10 \mathrm{ml}$ Milli $\mathrm{Q}$ water for 10 min. Remove the filter from the crucible.

Note: Before introducing any sample in the porcelain crucibles, weigh them when empty for further determination of the mass of dry matter.

8. Place the porcelain crucibles in an oven at $95{ }^{\circ} \mathrm{C}$ overnight to dry the sample. Figure 1 summarizes the protocol Steps A4 to A8.

9. Place the porcelain crucibles in a desiccator for $8 \mathrm{~h}$ for further drying.

10. Weigh the porcelain crucibles for further determination of the mass of dry matter.

Note: Steps A4 to A8 can be carried out with $100 \mathrm{ml}$ YD medium (without cells). This sample will be used as a blank for further measurement.

1.
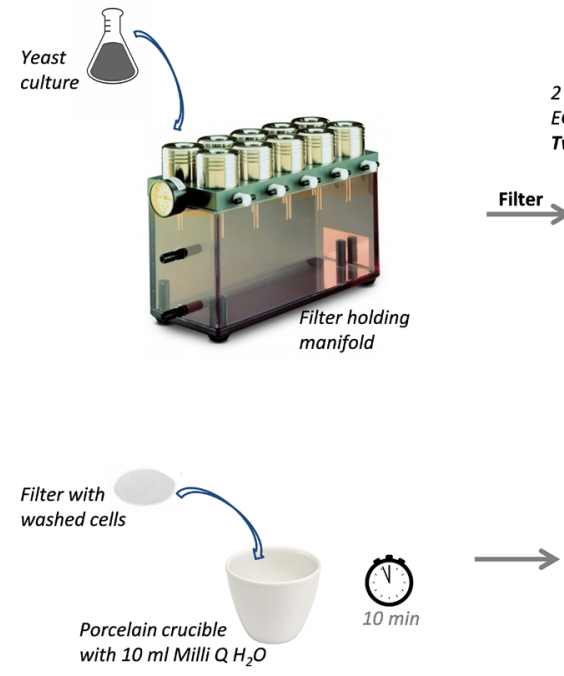

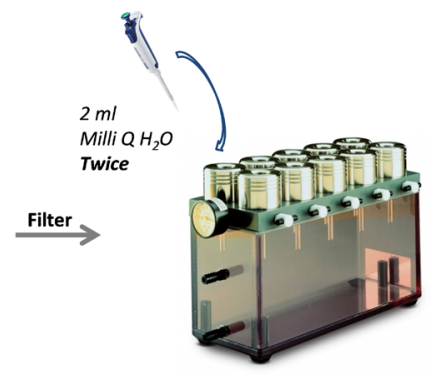

Figure 1. Experimental Steps A4 to A8. The $100 \mathrm{ml}$ yeast culture is first filtered. Then, cells on the filter are washed with EGTA $1 \mathrm{mM}$ (twice) and Milli $\mathrm{Q}$ water (twice). The filter with washed cells is subsequently immerged in a porcelain crucible containing $10 \mathrm{ml}$ Milli $\mathrm{Q}$ water. Finally, the filter is removed and the porcelain crucible is placed in an oven for further drying.

B. Measurement of the ionic content

1. Place the samples in the muffle furnace at $500^{\circ} \mathrm{C}$ for $4 \mathrm{~h}$.

2. Resuspend the ashes in $6.5 \%$ nitric acid $\left(0.5 \mathrm{ml}\right.$ nitric acid $65 \%+9.5 \mathrm{ml}$ Milli Q $\left.\mathrm{H}_{2} \mathrm{O}\right)$.

3. Dilute the ICP standards from Merck in a range of concentration that covers the expected ionic 
concentration in the samples to be analyzed. Acidify the standard solutions to $0.5 \%$ nitric acid (from $65 \%$ nitric acid). The standard concentrations used for measurement of yeast ionic content in our study are mentioned in Table 1.

4. Measure the emitted light for each standard and sample. Typical instrument parameters are given in Table 2. Table 3 gathers the wavelengths and the viewing mode used for measurement of each cation.

5. Deduce the ionic content in the samples using the calibration curve established from the standards (see Data analysis).

Table 1. Concentrations of the standards $(\mathrm{St})$ used for the calibration line

\begin{tabular}{llllll}
\hline Element & St 0 & St 1 & St 2 & St 3 & St 4 \\
\hline $\mathrm{Ba}$ & $0 \mathrm{ppm}$ & $0.5 \mathrm{ppm}$ & $1 \mathrm{ppm}$ & $2 \mathrm{ppm}$ & $4 \mathrm{ppm}$ \\
$\mathrm{Ca}$ & $0 \mathrm{ppm}$ & $2 \mathrm{ppm}$ & $4 \mathrm{ppm}$ & $10 \mathrm{ppm}$ & $20 \mathrm{ppm}$ \\
$\mathrm{Cd}$ & $0 \mathrm{ppb}$ & $5 \mathrm{ppb}$ & $10 \mathrm{ppb}$ & $20 \mathrm{ppb}$ & $40 \mathrm{ppb}$ \\
$\mathrm{Co}$ & $0 \mathrm{ppb}$ & $5 \mathrm{ppb}$ & $10 \mathrm{ppb}$ & $20 \mathrm{ppb}$ & $40 \mathrm{ppb}$ \\
$\mathrm{Cu}$ & $0 \mathrm{ppb}$ & $5 \mathrm{ppb}$ & $10 \mathrm{ppb}$ & $20 \mathrm{ppb}$ & $40 \mathrm{ppb}$ \\
$\mathrm{Fe}$ & $0 \mathrm{ppm}$ & $0.1 \mathrm{ppm}$ & $0.2 \mathrm{ppm}$ & $0.4 \mathrm{ppm}$ & $1 \mathrm{ppm}$ \\
$\mathrm{K}$ & $0 \mathrm{ppm}$ & $10 \mathrm{ppm}$ & $20 \mathrm{ppm}$ & $40 \mathrm{ppm}$ & $100 \mathrm{ppm}$ \\
$\mathrm{Mg}$ & $0 \mathrm{ppm}$ & $2 \mathrm{ppm}$ & $4 \mathrm{ppm}$ & $10 \mathrm{ppm}$ & $20 \mathrm{ppm}$ \\
$\mathrm{Mn}$ & $0 \mathrm{ppb}$ & $20 \mathrm{ppb}$ & $40 \mathrm{ppb}$ & $100 \mathrm{ppb}$ & $200 \mathrm{ppb}$ \\
$\mathrm{Na}$ & $0 \mathrm{ppm}$ & $10 \mathrm{ppm}$ & $20 \mathrm{ppm}$ & $40 \mathrm{ppm}$ & $100 \mathrm{ppm}$ \\
$\mathrm{Ni}$ & $0 \mathrm{ppb}$ & $5 \mathrm{ppb}$ & $10 \mathrm{ppb}$ & $20 \mathrm{ppb}$ & $40 \mathrm{ppb}$ \\
$\mathrm{Zn}$ & $0 \mathrm{ppb}$ & $200 \mathrm{ppb}$ & $400 \mathrm{ppb}$ & $1,000 \mathrm{ppb}$ & $2,000 \mathrm{ppb}$ \\
\hline
\end{tabular}

Table 2. Typical instrument parameters used on the Thermo Scientific ICAP 6500 ICP OES

\begin{tabular}{ll}
\hline Pump rate & $50 \mathrm{rpm}$ \\
Nebulizer & concentric \\
Center tube & $2 \mathrm{~mm}$ \\
Torch orientation & Duo (Axial and Radial view) \\
RF Power & $1150 \mathrm{~W}$ \\
Coolant Flow & $12 \mathrm{~L} / \mathrm{min}$ \\
Auxiliary flow & $0.6 \mathrm{~L} / \mathrm{min}$ \\
Integration Time & $15 \mathrm{~s}$ axial/20 s radial \\
\hline
\end{tabular}


Table 3. Wavelengths and viewing mode used for the twelve elements

\begin{tabular}{lll}
\hline Element & Wavelength(s) $\mathbf{( n m})$ & Viewing mode \\
\hline $\mathrm{Ba}$ & 455.403 & Radial \\
$\mathrm{Ca}$ & 317.933 & Radial \\
$\mathrm{Cd}$ & $226.502 ; 228.802$ & Axial \\
$\mathrm{Co}$ & $228.616 ; 230.786$ & Axial \\
$\mathrm{Cu}$ & 324.754 & Axial \\
$\mathrm{Fe}$ & 259.940 & Radial \\
$\mathrm{K}$ & 766.490 & Radial \\
$\mathrm{Mg}$ & $279.553 ; 285.213$ & Radial \\
$\mathrm{Mn}$ & 257.610 & Axial \\
$\mathrm{Na}$ & 589.592 & Radial \\
$\mathrm{Ni}$ & $216.556 ; 221.647 ; 231.604$ & Axial \\
$\mathrm{Zn}$ & $202.548 ; 206.200 ; 213.560$ & Radial \\
\hline
\end{tabular}

\section{Data analysis}

The calibration curve of the emitted light as a function of the concentration of the standards is first modelled using linear regression. The validation parameter for a calibration line is a $R^{2}$ coefficient of minimum 0.999. An example of calibration line is provided in Figure 2.

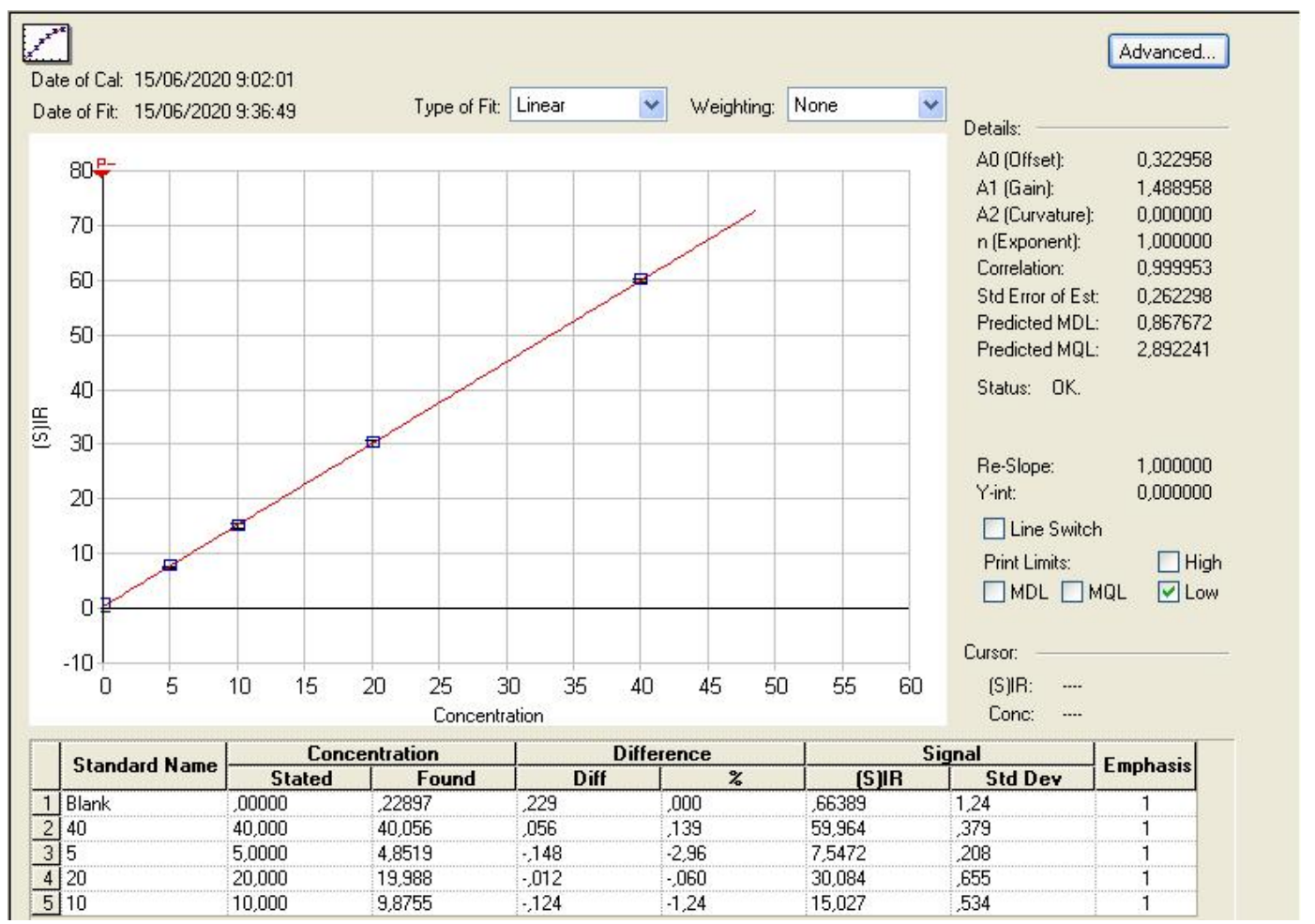

Figure 2. Calibration line of the emitted light according to the concentration of nickel $(\mathrm{ppb})$ in the five standard solutions 
The equation of the linear regression is determined as:

$$
\text { Emitted light }=A * \text { Concentration }+B
$$

with $A$ the slope of the line and $B$ its intercept. This equation is then used to deduce the concentration (in ppb or ppm) of the samples to be analyzed from the measurement of the intensity of the light emitted by the following equation:

$$
\text { Concentration }=\frac{\text { Emitted light }-B}{A}
$$

The ionic content obtained in ppm can then be converted into $\mu \mathrm{mol}$ of the ion per gram of yeast dry matter. To do so, first determine the mass of dry matter by subtracting the mass of the empty porcelain crucibles to that of the crucibles containing the cells after drying. Then convert the ionic concentration obtained in ppm to $\mu \mathrm{mol}$ of the ion per gram of dry matter according to the following formula:

$$
\frac{\mu \text { mol }_{\text {ion }}}{g_{\text {dry matter }}}=\left(\frac{\frac{p p m_{\text {ion }}}{100}}{g_{\text {dry matter }}}\right) * 1000 * 1 / M M_{\text {ion }}
$$

With MM the molar mass of the ion in $\mathrm{g} / \mathrm{mol}$.

The limit of quantification of each element is mentioned in Table 4.

Table 4. Limit of quantification for the twelve elements

\begin{tabular}{ll}
\hline Element & Limit of quantification \\
\hline $\mathrm{Ba}$ & $0.01 \mathrm{ppm}$ \\
$\mathrm{Ca}$ & $0.01 \mathrm{ppm}$ \\
$\mathrm{Cd}$ & $0.6 \mathrm{ppb}$ \\
$\mathrm{Co}$ & $0.5 \mathrm{ppb}$ \\
$\mathrm{Cu}$ & $1 \mathrm{ppb}$ \\
$\mathrm{Fe}$ & $0.01 \mathrm{ppm}$ \\
$\mathrm{K}$ & $0.05 \mathrm{ppm}$ \\
$\mathrm{Mg}$ & $0.01 \mathrm{ppm}$ \\
$\mathrm{Mn}$ & $0.5 \mathrm{ppb}$ \\
$\mathrm{Na}$ & $0.05 \mathrm{ppm}$ \\
$\mathrm{Ni}$ & $2 \mathrm{ppb}$ \\
$\mathrm{Zn}$ & $2 \mathrm{ppb}$ \\
\hline
\end{tabular}




\section{Recipes}

1. YD plates

$2 \mathrm{~g}(2 \% \mathrm{w} / \mathrm{v})$ yeast extract KAT

$2 \mathrm{~g}(2 \% \mathrm{w} / \mathrm{v})$ glucose

$2 \mathrm{~g}(2 \% \mathrm{w} / \mathrm{v})$ agar

Adjust to $100 \mathrm{ml}$ with Milli $\mathrm{Q}$ water and autoclave

Pour in Petri dishes

2. YD medium

$2 \mathrm{~g}(2 \% \mathrm{w} / \mathrm{v})$ yeast extract KAT

$2 \mathrm{~g}(2 \% \mathrm{w} / \mathrm{v})$ glucose

Adjust to $100 \mathrm{ml}$ with Milli $\mathrm{Q}$ water and autoclave

3. 1 mM EGTA ( $1 \mathrm{~L})$

$0.3804 \mathrm{~g}$ EGTA

Adjust $\mathrm{pH}$ to 8.0 with $\mathrm{NaOH}$

\section{Acknowledgments}

The work was supported by grants from the Fonds National de la Recherche Scientifique (FNRS, grant PDR-T.0206.16). L.T. is a research fellow at the 'Fonds pour le Formation à la Recherche dans I'Industrie et dans I'Agriculture'. We thank Anne-Sophie Colinet for prior protocol development.

\section{Competing interests}

The authors declare that they have no conflicts of interest with the contents of this article.

\section{References}

1. Thines, L., Deschamps, A., Sengottaiyan, P., Savel, O., Stribny, J. and Morsomme, P. (2018). The yeast protein Gdt1p transports $\mathrm{Mn}^{2+}$ ions and thereby regulates manganese homeostasis in the Golgi. J Biol Chem 293(21): 8048-8055.

2. Dahlquist, R. L., and Knoll, J. W. (1978). Inductively Coupled Plasma-Atomic Emission Spectrometry: Analysis of Biological Materials and Soils for Major, Trace, and Ultra-trace Elements. App/ Spectrosc 32(1):1-30.

3. Eide, D. J., Clark, S., Nair, T. M., Gehl, M., Guerinot, M. L., and Harper, J. F. (2005). Characterization of the yeast ionome: a genome-wide analysis of nutrient mineral and trace element homeostasis in Saccharomyces cerevisiae. Genome Biol 6(9):R77. 